\title{
Moorella humiferrea sp. nov., a thermophilic, anaerobic bacterium capable of growth via electron shuttling between humic acid and Fe(III)
}

Correspondence

A. I. Slobodkin aslobodkin@hotmail.com

\author{
Y. N. Nepomnyashchaya, ${ }^{1}$ G. B. Slobodkina, ${ }^{2}$ R. V. Baslerov, ${ }^{3}$ \\ N. A. Chernyh, ${ }^{1}$ E. A. Bonch-Osmolovskaya, ${ }^{2}$ A. I. Netrusov ${ }^{1}$ \\ and A. I. Slobodkin ${ }^{2}$ \\ ${ }^{1}$ Lomonosov Moscow State University, Leninskie Gory 1, 119991 Moscow, Russia \\ ${ }^{2}$ Winogradsky Institute of Microbiology, Russian Academy of Sciences, \\ Prospect 60-letiya Oktyabrya 7/2, 117312 Moscow, Russia \\ ${ }^{3}$ Bioengineering Center, Russian Academy of Sciences, Prospect 60-letiya Oktyabrya 7/1, \\ 117312 Moscow, Russia
}

Microbial Fe(III) reduction is a global biogeochemical process that contributes significantly to the cycling of iron and carbon in different biotopes, including thermal ecosystems (Lovley et al., 2004; Slobodkin, 2005). At neutral $\mathrm{pH}, \mathrm{Fe}(\mathrm{III})$ exists as insoluble, solid-phase minerals, mostly iron oxides. Electron transfer from dissimilatory iron-reducing micro-organisms to iron(III) oxides can be achieved either by direct contact between the cell and the mineral or by soluble electron shuttles (Lovley et al., 2004). One of the most studied exogenous electron-shuttling compounds is humic acid or its synthetic analogue 9,

Abbreviation: AQDS, 9,10-anthraquinone-2,6-disulfonate.

The GenBank/EMBL/DDBJ accession number for the 16S rRNA gene sequence of strain $64-\mathrm{FGQ}^{\top}$ is GQ872425. 10-anthraquinone-2,6-disulfonate (AQDS); even small quantities of these substances significantly stimulate Fe(III) reduction (Lovley et al., 1996). It is assumed that humic substances derived from the surrounding soil are present in terrestrial hydrothermal systems. Several thermophilic and hyperthermophilic micro-organisms are known to use humic acid or AQDS as an electron acceptor (Slobodkin et al., 1997a; Lovley et al., 2000). However, direct enrichment and isolation of thermophiles in the presence of these compounds has not been performed, and the ecological role of different taxonomic groups of thermophilic prokaryotes in the reduction of $\mathrm{Fe}(\mathrm{III})$ and humic compounds in natural ecosystems is virtually unknown. In this paper, we describe a novel anaerobic, thermophilic bacterium (designated strain $64-\mathrm{FGQ}^{\mathrm{T}}$ ) isolated from a 
terrestrial hydrothermal spring. Although strain $64-\mathrm{FGQ}^{\mathrm{T}}$ cannot directly reduce $\mathrm{Fe}(\mathrm{III})$, it is capable of reducing humic acid and thus could be involved in the electron flow from organic matter to ferric iron compounds in thermal environments.

Strain $64-\mathrm{FGQ}^{\mathrm{T}}$ was isolated from a sample of sediment collected in a freshwater hot spring originating from the Grot geyser located near the Geysernaya river, Geyser Valley, Kamchatka, Russia. The banks of the spring 20$30 \mathrm{~cm}$ from the sampling site $\left(54^{\circ} 26.288^{\prime} \mathrm{N} 160^{\circ} 08.433^{\prime}\right.$ E) were covered with grass. The water at the sampling site was at $78{ }^{\circ} \mathrm{C}, \mathrm{pH} 7.7$ and $\mathrm{E}_{\mathrm{h}}$ varied from -10 to $-60 \mathrm{mV}$. The sample of sediment used for inoculation consisted of three layers that were ochre, grey and black in colour; each layer had a thickness of about $0.5 \mathrm{~cm}$. To isolate microorganisms with the ability to reduce insoluble $\mathrm{Fe}(\mathrm{III})$ compounds without direct contact of the cells with the mineral, poorly crystalline iron(III) oxide (ferrihydrite) was incorporated into alginate beads and AQDS was provided as an electron shuttle. An enrichment culture was initiated by inoculating $10 \%(\mathrm{w} / \mathrm{v})$ of the sample into anaerobically prepared, bicarbonate-buffered, sterile $\left(135^{\circ} \mathrm{C}, 1 \mathrm{~h}\right)$ liquid medium with lactate $(12 \mathrm{mM})$ as an electron donor, ferrihydrite [90 mmol $\mathrm{Fe}(\mathrm{III}) \mathrm{l}^{-1}$ ] incorporated into microporous alginate beads as a potential electron acceptor and AQDS $(0.1 \mathrm{mM})$ as an electron shuttle. Inoculation was performed anaerobically under $100 \% \mathrm{CO}_{2}$. Composition of the medium and preparation techniques were as described previously (Slobodkin et al., 1999). Alginate beads were prepared as described by Nevin \& Lovley (2000). After incubation of enrichment cultures at $65{ }^{\circ} \mathrm{C}$ for $7-30$ days the colour of the beads changed from brown to black, indicating Fe(III) reduction. A pure culture was obtained from an enrichment positive for $\mathrm{Fe}(\mathrm{III})$ reduction by means of serial dilutions in the same medium followed by the selection of well-separated colonies that had developed in anaerobic agar blocks [1.5\% agar in growth medium with $20 \mathrm{mM}$ AQDS from which $\mathrm{Fe}(\mathrm{III})$-containing alginate beads were omitted]. The process of obtaining separate colonies was subsequently repeated four times. Finally, the single colony that had developed in the highest positive agar shake dilution $\left(10^{-8}\right)$ was designated strain $64-\mathrm{FGQ}^{\mathrm{T}}$ and was used for further studies. Denaturing gradient gel electrophoresis of the outgrown cultures of strain $64-\mathrm{FGQ}^{\mathrm{T}}$ performed as described by Slobodkina et al. (2009) revealed a single band and thus additionally confirmed the purity of the culture. Physiological studies on substrate utilization, and on temperature, $\mathrm{pH}$ and salinity ranges for growth, were carried out in medium containing $20 \mathrm{mM}$ AQDS unless noted otherwise. All electron donors and acceptors were tested in the presence of $0.2 \mathrm{~g}$ yeast extract $\mathrm{l}^{-1}$. AQDS was omitted in experiments examining utilization of electron acceptors.

Light and electron microscopy, Gram staining, analytical techniques for $\mathrm{Fe}$ (II) determination and analysis of other metabolic products, genomic DNA extraction, determination of the $\mathrm{G}+\mathrm{C}$ content and DNA-DNA hybridization studies were performed as described by Slobodkin et al. (1999). The 16S rRNA gene was selectively amplified from genomic DNA by PCR using forward and reverse primers $11 \mathrm{~F}$ and 1492R (Lane, 1991). PCR was carried out in a $50 \mu \mathrm{l}$ reaction mixture containing 50 ng DNA template, 5 pmol (each) primer, $12.5 \mathrm{nmol}$ (each) dNTP and 3 U Taq DNA polymerase (Fermentas) in Taq DNA polymerase reaction buffer (Fermentas). The temperature cycling programme consisted of a first cycle of 9 min at $94{ }^{\circ} \mathrm{C}, 1 \mathrm{~min}$ at $55{ }^{\circ} \mathrm{C}$ and $2 \mathrm{~min}$ at $72{ }^{\circ} \mathrm{C}$, followed by 30 amplification cycles of $1 \mathrm{~min}$ at $94{ }^{\circ} \mathrm{C}, 1 \mathrm{~min}$ at $55^{\circ} \mathrm{C}$ and $1 \mathrm{~min}$ at $72{ }^{\circ} \mathrm{C}$, and a final extension at $72{ }^{\circ} \mathrm{C}$ for $7 \mathrm{~min}$. PCR products were purified by using the Wizard PCRPreps kit (Promega) as recommended by the manufacturer. The $16 \mathrm{~S}$ rRNA gene was sequenced in both directions with Big Dye Terminator v.3.1 (Applied Biosystems) as described in the manufacturer's instructions by using an ABI PRISM 3730 sequencer (Applied Biosystems). The sequences were assembled and checked for accuracy manually by using the alignment editor BioEdit v5.0.9 (Hall, 1999). The fulllength $16 \mathrm{~S}$ rRNA gene sequence of strain $64-\mathrm{FGQ}^{\mathrm{T}}$ was compared with other sequences in GenBank (Benson et al., 1999) via BLAST (Altschul et al., 1997) to identify its closest relatives. Alignment with a representative set of other $16 \mathrm{~S}$ rRNA gene sequences in GenBank was carried out by using the CLUSTAL $\mathrm{W}$ program provided by the phylogenetic analysis package MEGA version 4 (Tamura et al., 2007) and was then adjusted manually. Pairwise similarity values were calculated by means of EzTaxon (Chun et al., 2007). A phylogenetic dendrogram was constructed by the neighbour-joining method (Saitou \& Nei, 1987) with the Maximum Composite Likelihood model (Tamura et al., 2004) by using MEGA version 4 . Reference strain Moorella glycerini JW/AS-Y6 $6^{\mathrm{T}}\left(=\mathrm{DSM} 11254^{\mathrm{T}}\right)$ used in physiological and DNA-DNA hybridization studies was obtained from the culture collection of the Laboratory of Hyperthermophilic Microbial Communities, Winogradsky Institute of Microbiology; this strain was routinely cultured in medium with glycerol as described by Slobodkin et al. (1997b).

Colonies of strain $64-\mathrm{FGQ}^{\mathrm{T}}$ appearing in agar shake cultures after $48-120 \mathrm{~h}$ incubation at $65{ }^{\circ} \mathrm{C}$ were white, circular and $1.5-2.0 \mathrm{~mm}$ in diameter. Vegetative cells of strain $64-\mathrm{FGQ}^{\mathrm{T}}$ were straight rods, $0.3-0.5 \mu \mathrm{m}$ in diameter and $2.0-5.0 \mu \mathrm{m}$ long. Cells occurred singly or in short chains and exhibited tumbling motility due to peritrichous flagella. Strain $64-\mathrm{FGQ}^{\mathrm{T}}$ formed round, refractive endospores in terminally swollen sporangia. Cells stained Grampositive in both exponential and stationary growth phases. Ultrathin sectioning of cells of strain $64-\mathrm{FGQ}^{\mathrm{T}}$ revealed a distinct peptidoglycan layer in the cell wall. The temperature range for growth of strain $64-\mathrm{FGQ}^{\mathrm{T}}$ was $46-70{ }^{\circ} \mathrm{C}$, with optimum at $65{ }^{\circ} \mathrm{C}$. No growth was detected at 37 or $75{ }^{\circ} \mathrm{C}$ after incubation for 2 weeks. The $\mathrm{pH}$ range for growth was 5.5-8.5, with optimum at $\mathrm{pH}$ 7.0. No growth was detected at $\mathrm{pH} 5.0$ or 9.0. Growth of strain $64-\mathrm{FGQ}^{\mathrm{T}}$ 
was observed at $\mathrm{NaCl}$ concentrations ranging from 0 to $1.5 \%(\mathrm{w} / \mathrm{v})$, with optimum at $0 \%(\mathrm{w} / \mathrm{v})$, but no growth was evident at $2.0 \%(\mathrm{w} / \mathrm{v})$. The generation time under optimal conditions in medium with lactate and AQDS was $126 \mathrm{~min}$. Strain $64-\mathrm{FGQ}^{\mathrm{T}}$ utilized lactate $(12 \mathrm{mM})$, malate, succinate, glycerol (each substrate at $20 \mathrm{mM}$ ) and yeast extract $\left(0.2 \mathrm{~g} \mathrm{l}^{-1}\right)$ with AQDS as electron acceptor. Lactate was incompletely oxidized to acetate as the only metabolic product; no molecular hydrogen was produced. In the absence of AQDS, no growth on these substrates was observed. Yeast extract at a concentration of at least $50 \mathrm{mg} \mathrm{l}^{-1}$ was required for growth. In the absence of AQDS, strain $64-\mathrm{FGQ}^{\mathrm{T}}$ fermented galactose, fructose, maltose, sucrose, pyruvate (each at $20 \mathrm{mM}$ ) and peptone $\left(10 \mathrm{~g} \mathrm{l}^{-1}\right)$. The main product of fructose fermentation was acetate. Carbohydrates chemically reduced AQDS in sterile controls, and thus tests for growth with AQDS and carbohydrates were not performed. Strain $64-\mathrm{FGQ}^{\mathrm{T}}$ grew on pyruvate and peptone in the presence as well as in the absence of AQDS; growth rate and cell yield were the same under the two conditions. The following substrates were tested but were not utilized for growth in the absence or presence of AQDS: $\mathrm{H}_{2} / \mathrm{CO}_{2}(80: 20, \mathrm{v} / \mathrm{v})$, formate, acetate, propionate, butyrate, oxalate, fumarate, methanol, ethanol, n-propanol, butanol, benzoate, acetone, glycine, valine, alanine, glucose, mannose, cellobiose, xylose, arabinose (each substrate at $20 \mathrm{mM}$ ), filter paper, alginate, starch and olive oil (each at $10 \mathrm{~g} \mathrm{l}^{-1}$ ). Strain $64-\mathrm{FGQ}^{\mathrm{T}}$ reduced AQDS (20 mM) to 9,10-anthrahydroquinone-2,6-disulfonate, thiosulfate $(10 \mathrm{mM})$ to sulfide, nitrate $(10 \mathrm{mM})$ to nitrite and ammonia, and perchlorate $(10 \mathrm{mM})$ to chloride with lactate as electron donor. The isolate was able to grow (maximal cell concentration $1.0 \times 10^{8}$ cells $1^{-1}$ ) with humic acid (humic acid, sodium salt; Aldrich, $1.0 \mathrm{~g}^{-1}$ ) as an electron acceptor and lactate as electron donor. Strain 64$\mathrm{FGQ}^{\mathrm{T}}$ was not able to reduce ferrihydrite $[90 \mathrm{mmol} \mathrm{Fe}(\mathrm{III})$ $\mathrm{l}^{-1}$ ], $\mathrm{Fe}(\mathrm{III})$-EDTA $(10 \mathrm{mM})$, iron(III) citrate $(10 \mathrm{mM})$, $\mathrm{MnO}_{2} \quad\left(25 \mathrm{mmol} \mathrm{l}^{-1}\right)$, fumarate $(10 \mathrm{mM})$, sulfate $(14 \mathrm{mM})$, sulfite $(5 \mathrm{mM})$, elemental sulfur $\left(150 \mathrm{mmol} \mathrm{l}^{-1}\right)$ or oxygen $[0.5,1.0,3.0$ or $20 \%(\mathrm{v} / \mathrm{v})$ in the gas phase] with lactate or glycerol as electron donors. The isolate was able to grow and reduce ferrihydrite $\left[90 \mathrm{mmol} \mathrm{Fe}(\mathrm{III}) \mathrm{l}^{-1}\right.$ ] suspended in the cultivation medium or incorporated into alginate beads in the presence of AQDS or humic acid as electron-shuttling compounds. The minimal concentrations of AQDS and humic acid that supported growth (3$7 \times 10^{7}$ cells $\mathrm{ml}^{-1}$ ) and $\mathrm{Fe}(\mathrm{III})$ reduction $[4.0-7.0 \mathrm{mmol}$ $\mathrm{Fe}(\mathrm{II}) \mathrm{l}^{-1}$ produced] were $0.05 \mathrm{mM}$ and $0.25 \mathrm{~g} \mathrm{l}^{-1}$, respectively. Ampicillin, chloramphenicol, erythromycin, rifampicin and tetracycline completely inhibited growth at a concentration of $100 \mu \mathrm{g} \mathrm{ml}^{-1}$. Streptomycin $(100 \mu \mathrm{g}$ $\mathrm{ml}^{-1}$ ) did not inhibit growth.

Strain $64-\mathrm{FGQ}^{\mathrm{T}}$ provides a first example of an organism that was enriched and isolated by using a soluble compound providing the electron transfer between organic substances and insoluble iron(III) oxide. Incorporation of ferrihydrite into alginate beads and thus preventing direct contact of the cell with the mineral allowed us to select for micro-organisms involved in $\mathrm{Fe}$ (III) reduction via shuttling of electron-transferring molecules. The important role of humic acid-reducing bacteria in indirect $\mathrm{Fe}$ (III) reduction was suggested for freshwater lake sediments (Kappler et al., 2004). Our results indicate that in thermal environments, relatively low concentrations of humic acid and possibly other quinone-containing compounds can provide sustainable microbial growth and oxidation of organic matter coupled to $\mathrm{Fe}(\mathrm{III})$ reduction.

The $\mathrm{G}+\mathrm{C}$ content of the genomic DNA of strain $64-\mathrm{FGQ}^{\mathrm{T}}$ was $51 \mathrm{~mol} \%\left(T_{\mathrm{m}}\right)$. Phylogenetic analysis showed that highest levels of $16 \mathrm{~S}$ rRNA gene sequence similarity were found with species of the genus Moorella within the Firmicutes (Fig. 1). A comparison of $1488 \mathrm{nt}$ of the $16 \mathrm{~S}$ rRNA gene sequence of strain $64-\mathrm{FGQ}^{\mathrm{T}}$ showed that it was related most closely to the type strain of $M$. glycerini (Slobodkin et al., 1997b) with which it shared 97.2\% similarity. Strain $64-\mathrm{FGQ}^{\mathrm{T}}$ was similar to all recognized Moorella species in cell morphology, endospore formation and thermophilic nature, but it shared only $94.2-94.9 \%$ 16S rRNA gene sequence similarity with the type strains of other members of the genus Moorella except M. glycerini. Therefore, strain 64-FGQ ${ }^{\mathrm{T}}$ cannot be assigned to Moorella thermoacetica (Fontaine et al., 1942), Moorella thermoautotrophica (Wiegel et al., 1981) or Moorella mulderi (Balk et al., 2003), irrespective of its physiological traits. Given that the level of $16 \mathrm{~S}$ rRNA gene sequence similarity

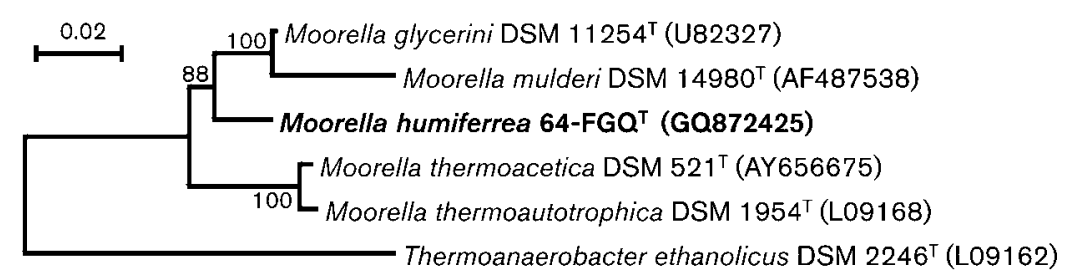

Fig. 1. Phylogenetic tree based on $16 \mathrm{~S}$ rRNA gene sequences indicating the position of strain $64-\mathrm{FGQ}^{\top}$ among members of the genus Moorella. The tree was constructed by using the neighbour-joining algorithm; application of the maximum-parsimony and minimal-evolution methods did not change the topology of the tree. The sequence from Thermoanaerobacter ethanolicus DSM $2246^{\top}$ was used as the outgroup. GenBank accession numbers are given in parentheses. Numbers at nodes are bootstrap values (500 replications); only values $>70 \%$ are shown. Bar, 2 substitutions per 100 nt. 
between strain $64-\mathrm{FGQ}^{\mathrm{T}}$ and the type strain of $M$. glycerini was more than $97 \%$, quantitative DNA-DNA hybridization experiments were performed. The level of DNA-DNA relatedness between strain $64-\mathrm{FGQ}^{\mathrm{T}}$ and $M$. glycerini JW/AS-Y $6^{\mathrm{T}}$ was $17 \%$. These data indicate that strain 64 $\mathrm{FGQ}^{\mathrm{T}}$ represents a novel species of the genus Moorella. Furthermore, strain $64-\mathrm{FGQ}^{\mathrm{T}}$ could be differentiated from M. glycerini based on a number of physiological characteristics such as temperature range and optimum for growth and utilization of electron donors and acceptors (Table 1). M. glycerini is not able to use humic acid or AQDS as electron acceptors for growth, which is a hallmark feature of strain $64-\mathrm{FGQ}^{\mathrm{T}}$. Therefore, on the basis of physiological properties and the results of phylogenetic analysis we suggest that strain $64-\mathrm{FGQ}^{\mathrm{T}}$ represents a novel species of the genus Moorella, for which the name Moorella humiferrea sp. nov. is proposed.

\section{Description of Moorella humiferrea sp. nov.}

Moorella humiferrea (hu.mi.fer're.a. L. n. humus humus; L. adj. ferreus made of or referring to iron; N.L. fem. adj. humiferrea pertaining to humic substances and iron).

Cells are straight rods, $0.3-0.5 \mu \mathrm{m}$ in diameter and 2.0 $5.0 \mu \mathrm{m}$ long. Cells occur singly or in short chains and exhibit tumbling motility due to peritrichous flagella. Gram-stain-positive. Produces round, refractive endospores in terminally swollen sporangia. The temperature range for growth is $46-70{ }^{\circ} \mathrm{C}$, with optimum at $65^{\circ} \mathrm{C}$. The $\mathrm{pH}$ range for growth is 5.5-8.5, with optimum at $\mathrm{pH} 6.8-$ 7.0. Growth occurs at $\mathrm{NaCl}$ concentrations of $0-1.5 \%$ $(\mathrm{w} / \mathrm{v})$. Anaerobic. Substrates utilized in the presence of AQDS include lactate, malate, succinate, glycerol and yeast extract. Lactate is incompletely oxidized to acetate as the only metabolic product. In the absence of AQDS, no growth

Table 1. Differential characteristics of strain $64-\mathrm{FGQ}^{\top}$ and Moorella glycerini

All characteristics were determined in this study.

\begin{tabular}{|c|c|c|}
\hline Characteristic & $\begin{array}{c}\text { Strain } \\
\text { 64-FGQ }\end{array}$ & M. glycerini \\
\hline $\begin{array}{l}\text { Temperature range for growth } \\
\left({ }^{\circ} \mathrm{C}\right)\end{array}$ & $46-70$ & $43-65$ \\
\hline Optimum temperature $\left({ }^{\circ} \mathrm{C}\right)$ & 65 & 58 \\
\hline \multicolumn{3}{|l|}{ Utilization of: } \\
\hline Glucose & - & + \\
\hline Sucrose & + & - \\
\hline Mannose & - & + \\
\hline \multicolumn{3}{|l|}{ Reduction of: } \\
\hline Nitrate & + & - \\
\hline AQDS & + & - \\
\hline Fumarate & - & + \\
\hline $\begin{array}{l}\text { End product of thiosulfate } \\
\text { reduction }\end{array}$ & Sulfide & $\begin{array}{l}\text { Elemental } \\
\text { sulfur }\end{array}$ \\
\hline
\end{tabular}

on these substrates is observed. Yeast extract is required for growth. Ferments galactose, fructose, maltose, sucrose, pyruvate and peptone. Grows on pyruvate and peptone in the presence as well in the absence of AQDS. $\mathrm{H}_{2} / \mathrm{CO}_{2}$, formate, acetate, propionate, butyrate, oxalate, methanol, ethanol, propanol, butanol, benzoate, acetone, glucose, mannose, cellobiose, xylose, arabinose, filter paper, alginate, starch and olive oil are not utilized with or without an exogenous electron acceptor. The main product of fructose fermentation is acetate. Reduces AQDS, thiosulfate, nitrate and perchlorate, but not ferrihydrite, iron(III) citrate, $\mathrm{MnO}_{2}$, fumarate, sulfate, sulfite, elemental sulfur or oxygen $[0.5,1.0,3$ or $20 \%(\mathrm{v} / \mathrm{v})$ in the gas phase]. Able to grow and reduce $\mathrm{Fe}(\mathrm{III})$ in the presence of small amounts of AQDS or humic acid as electron-shuttling compounds.

The type strain, $64-\mathrm{FGQ}^{\mathrm{T}} \quad\left(=\mathrm{DSM} \quad 23265^{\mathrm{T}}=\mathrm{VKM}\right.$ $\left.\mathrm{B}-2603^{\mathrm{T}}\right)$, was isolated from a terrestrial hot spring in Kamchatka, Russia. The DNA G + C content of the type strain is $51 \mathrm{~mol} \%$.

\section{Acknowledgements}

This work was supported by the Russian Foundation for Basic Research (grant 09-04-00251-a) and by the programmes 'Molecular and cell biology' and 'The origin and evolution of the biosphere' of the Russian Academy of Sciences.

\section{References}

Altschul, S. F., Madden, T. L., Schäffer, A. A., Zhang, J., Zhang, Z., Miller, W. \& Lipman, D. J. (1997). Gapped BLAST and PSI-BLAST: a new generation of protein database search programs. Nucleic Acids Res 25, 3389-3402.

Balk, M., Weijma, J., Friedrich, M. W. \& Stams, A. J. M. (2003). Methanol utilization by a novel thermophilic homoacetogenic bacterium, Moorella mulderi sp. nov., isolated from a bioreactor. Arch Microbiol 179, 315-320.

Benson, D. A., Boguski, M. S., Lipman, D. J., Ostell, J., Ouellette, B. F., Rapp, B. A. \& Wheeler, D. L. (1999). GenBank. Nucleic Acids Res 27, 12-17.

Chun, J., Lee, J.-H., Jung, Y., Kim, M., Kim, S., Kim, B. K. \& Lim, Y. W. (2007). EzTaxon: a web-based tool for the identification of prokaryotes based on 16S ribosomal RNA gene sequences. Int J Syst Evol Microbiol 57, 2259-2261.

Fontaine, F. E., Peterson, W. H., McCoy, E., Johnson, M. J. \& Ritter, G. J. (1942). A new type of glucose fermentation by Clostridium thermoaceticum. J Bacteriol 43, 701-715.

Hall, T. A. (1999). BioEdit: a user-friendly biological sequence alignment editor and analysis program for Windows 95/98/NT. Nucleic Acids Symp Ser 41, 95-98.

Kappler, A., Benz, M., Schink, B. \& Brune, A. (2004). Electron shuttling via humic acids in microbial iron(III) reduction in a freshwater sediment. FEMS Microbiol Ecol 47, 85-92.

Lane, D. J. (1991). 16S/23S rRNA sequencing. In Nucleic Acid Techniques in Bacterial Systematics, pp. 115-175. Edited by E. Stackebrandt \& M. Goodfellow. Chichester: Wiley.

Lovley, D. R., Coates, J. D., Blunt-Harris, E. L., Phillips, E. J. P. \& Woodward, J. C. (1996). Humic substances as electron acceptors for microbial respiration. Nature 382, 445-448. 
Lovley, D. R., Kashefi, K., Vargas, M., Tor, J. M. \& Blunt-Harris, E. L. (2000). Reduction of humic substances and $\mathrm{Fe}$ (III) by hyperthermophilic micro-organisms. Chem Geol 169, 289-298.

Lovley, D. R., Holmes, D. E. \& Nevin, K. P. (2004). Dissimilatory $\mathrm{Fe}(\mathrm{III})$ and $\mathrm{Mn}(\mathrm{IV})$ reduction. Adv Microb Physiol 49, 219-286.

Nevin, K. P. \& Lovley, D. R. (2000). Lack of production of electronshuttling compounds or solubilization of $\mathrm{Fe}$ (III) during reduction of insoluble Fe(III) oxide by Geobacter metallireducens. Appl Environ Microbiol 66, 2248-2251.

Saitou, N. \& Nei, M. (1987). The neighbor-joining method: a new method for reconstructing phylogenetic trees. Mol Biol Evol 4, 406425.

Slobodkin, A. I. (2005). Thermophilic microbial metal reduction. Microbiology (English translation of Mikrobiologiia) 74, 501-514.

Slobodkin, A. I., Reysenbach, A.-L., Strutz, N., Dreier, M. \& Wiegel, J. (1997a). Thermoterrabacterium ferrireducens gen. nov., sp. nov., a thermophilic anaerobic dissimilatory $\mathrm{Fe}(\mathrm{III})$-reducing bacterium from a continental hot spring. Int J Syst Bacteriol 47, 541-547.

Slobodkin, A., Reysenbach, A. L., Mayer, F. \& Wiegel, J. (1997b). Isolation and characterization of the homoacetogenic thermophilic bacterium Moorella glycerini sp. nov. Int J Syst Bacteriol 47, 969-974.

Slobodkin, A. I., Tourova, T. P., Kuznetsov, B. B., Kostrikina, N. A., Chernyh, N. A. \& Bonch-Osmolovskaya, E. A. (1999). Thermoanaerobacter siderophilus sp. nov., a novel dissimilatory Fe(III)-reducing, anaerobic, thermophilic bacterium. Int J Syst Bacteriol 49, 1471-1478.

Slobodkina, G. B., Kolganova, T. V., Querellou, J., BonchOsmolovskaya, E. A. \& Slobodkin, A. I. (2009). Geoglobus acetivorans sp. nov., an iron(III)-reducing archaeon from a deep-sea hydrothermal vent. Int J Syst Evol Microbiol 59, 2880-2883.

Tamura, K., Nei, M. \& Kumar, S. (2004). Prospects for inferring very large phylogenies by using the neighbor-joining method. Proc Natl Acad Sci U S A 101, 11030-11035.

Tamura, K., Dudley, J., Nei, M. \& Kumar, S. (2007). MEGA4: molecular evolutionary genetics analysis (MEGA) software version 4.0. Mol Biol Evol 24, 1596-1599.

Wiegel, J., Braun, M. \& Gottschalk, G. (1981). Clostridium thermoautotrophicum species novum, a thermophile producing acetate from molecular hydrogen and carbon dioxide. Curr Microbiol 5, 255-260. 